УДК 342

DOI https://doi.org/10.17308/vsu.proc.law.2021.3/3548

\title{
ПОДВЕДОМСТВЕННОСТЬ И ПОДСУДНОСТЬ АДМИНИСТРАТИВНЫХ ДЕЛ В РОССИЙСКОЙ ФЕДЕРАЦИИ
}

\author{
К. В. Давыдов \\ Новосибирский государственный университет эконолики и управления \\ "НИНХ", Сибирский университет потребительской кооперации \\ Поступила в редакцию 25 августа 2021 г.
}

\begin{abstract}
Аннотация: анализируются тендениии эволюиии предлета Кодекса административного судопроизводства РФ 2015 г. Одной из основных проблел обозначается определение прочессуального закона, применилого к административныл делал, связанныли с гражданско-правовыли требованияли. Подвергается критике сложившиеся правовое регулирование и судебная практика, исходящие из необходилости расслотрения таких дел по правилал гражданского процессуального законодательства. Форлулируются предложения по совершенствованию адлинистративного процессуального законодательства и судебной практики в части подведолственности и подсудности административных дел.
\end{abstract}

Ключевые слова: административное судопроизводство, адлинистративное дело, подведомственность, подсудность, Кодекс административного судопроизводства РФ.

\begin{abstract}
Code of Administrative Proceedings of the Russian Federation, adopted in 2015. One of the main problems is the definition of the procedural law applicable to administrative cases related to civil law requirements. The established legal regulation and judicial practice, based on considering such cases according to the rules of civil proceeding legislation, are criticized. Proposals for improving of administrative proceeding legislation and judicial practice in terms of jurisdiction of administrative cases are formulated.
\end{abstract}

Key words: administrative proceedings, administrative case, jurisdiction, Code of Administrative Proceeding of the Russian Federation.

Развитие административного судопроизводства в Российской Федера-

164 ции имеет достаточно давнюю и непростую историю. Одним из ключевых событий следует признать принятие и введение в действие с 15 сентября 2015 г. Кодекса административного судопроизводства РФ (пришедшего на смену соответствующей главе о публичном производстве ГПК РФ 2002 г.). При этом практика оспаривания незаконных нормативных и правоприменительных актов в российских судах достаточно богата, а позиция административных истцов - активна. Особенно отраден тот фракт, что оспаривание незаконных административных актов осуществляется не только гражданами (организациями), органами прокураторы, но и иными государственными органами.

(C) Давыдов К. В., 2021 
В качестве примера приведем спор между органом исполнительной власти Новосибирской области (Департаментом по тарифам Новосибирской области) и Федеральной антимонопольной службой (федеральным органом исполнительной власти, руководство деятельностью которым осу ществляет Правительство РФ). Решениями ФАС РФ были признаны обоснованными требования энергоснабжающей компании (АО «СИБЭКО») об увеличении тарифов в сфере теплоснабжения. Департамент по тарифрам Новосибирской области обратился в Арбитражный суд г. Москвы с административным иском о признании соответствующих решений ФАС России незаконными (ввиду в том числе нарушения требований утвержденных постановлением Правительства РФ от 22.10.2012 № 1075 Основ ценообразования). Примечательно, что одним из оснований иска было указание на тот фракт, что исполнение решений ФАС приводило к увеличению тарифов для населения сверх установленных на указанный период лимитов и повышению социальной напряженности в регионе, со ссылкой на информацию из СМИ: «Во исполнение Решений ФАС № 1, 2 Департамент 28.06.2019 приказом № 181-ТЭ изменил тарифы на тепловую энергию (мощность), поставляемую АО «СИБЭКО» всем потребителям на территории Новосибирской области на долгосрочный период регулирования 2019-2023 гг., что привело к росту тарифов на 7,2 \% (относительно тарифов на I полугодие 2019 г.). Оспариваемые решения повлекли увеличение платы граждан на территории области сверх предельного индекса - 3,2 \% и повлияли на права неограниченного круга лиц - всех потребителей тепловой энергии, могут повлечь социальную напряженность в регионе (по данным СМИ на август месяц)». Суд признал оспариваемые решения ФАС незаконными ${ }^{1}$.

Вместе с тем одной из важных проблем следует признать вопрос определения подведомственности и подсудности административных дел, сопряженных с гражданско-правовыми требованиями.

В одной из первоначальных редакций проекта КАС РФ предполагалось безусловное распространение норм об административном судопроизводстве на указанные категории дел. Однако при принятии соответствующая норма из итогового варианта кодекса по труднообъяснимым причинам исчезла. Возникшая неопределенность привела к разнонаправленности судебной практики. Что в свою очередь потребовало централизованных усилий со стороны Верховного Суда РФ. В ключевом в настоящее время постановлении пленума (от 27 сентября 2016 г. № 36 «О некоторых вопросах применения судами Кодекса административного судопроизводства Российской Федерации»²) Суд сформулировал ряд правовых позиций.

Во-первых, Верховный Суд РФ в п. 1 констатировал очевидное: «К административным делам, рассматриваемым по правилам КАС РФ, от-

${ }^{1}$ См.: Решение Арбитражного суда города Москвы от 5 декабря 2019 г. по делу № A40-171841/19-122-1404. Доступ из справ.-правовой системы «КонсультантПлюс».

${ }^{2}$ Доступ из справ.-правовой системы «КонсультантПлюс». 


\section{Вестник ВГУ. Серия: Право}

носятся дела, возникающие из правоотношений, не основанных на равенстве, автономии воли и имущественной самостоятельности их участников, в рамках которых один из участников правоотношений реализует административные и иные публично-властные полномочия по исполнению и применению законов и подзаконных актов по отношению к другому участнику».

Однако затем произошло довольно печальное сокращение сферы применения КАС РФ: «По смыслу части 4 статьи 1 КАС РФ и части 1 статьи 22 Гражданского процессуального кодекса Российской Федерации (далее - ГПК РФ), а также с учетом того, что гражданские права и обязанности возникают, в частности, из актов государственных органов и органов местного самоуправления (статья 8 Гражданского кодекса Российской Федерации (далее - ГК РФ), споры о признании таких актов недействительными (незаконными), если их исполнение привело к возникновению, изменению или прекращению гражданских прав и обязанностей, не подлежат рассмотрению в порядке, предусмотренном КАС РФ».

Наконец, в-третьих, данная более чем спорная правовая позиция была тут же «усилена» следующим умозаключением Суда: «Например, не подлежат рассмотрению по правилам КАС РФ служебные споры, в том числе дела, связанные с доступом и прохождением различных видов государственной службы, муниципальной службы, а также дела, связанные с назначением и выплатой пенсий, реализацией гражданами социальных прав, дела, связанные с предоставлением жилья по договору социального найма, договору найма жилищного фонда социального использования, договору найма специализированного жилищного фонда». В 2018 г. КАС РФ был дополнен ст. 16.1 («Переход к рассмотрению дела по правилам гражданского судопроизводства») $)^{3}$, легализовавшей суть ๓ вышеупомянутой правовой позиции Верховного Суда РФ. Таким образом, из сфреры административного судопроизводства разом было исключено существенное число административных дел. Трудно не согласиться с критикой подобной деструктивной позиции законодателя и судов, ведущей к необоснованному ограничению процессуальных прав граждан и организаций ${ }^{4}$.

При этом данный ход, как представляется, не устранил имевшую ме-

166 сто неопределенность. В качестве примера можно привести следующие судебные решения.

Гражданка обратилась в суд с иском к администрации городского района о признании права состоять на учете в качестве нуждающейся в предоставлении жилого помещения по договору социального найма, ссылаясь на то, что ее обращение в администрацию с заявлением о постановке на жилищный учет в качестве нуждающейся в предоставлении жилого помещения по договору социального найма отклонено в связи с тем, что она не имеет регистрации по месту жительства. Между тем истец проживает в городе более 10 лет, что ответчиком не

${ }^{3}$ Доступ из справ.-правовой системы «КонсультантПлюс».

${ }^{4}$ См., например: Опалев P. О. Предмет судебной защиты в административном судопроизводстве // Арбитражный и гражданский процесс. 2021. № 4. С. 18-22. 
оспаривается, поэтому имеет право состоять на учете граждан, нуждающихся в улучшении жилищных условий. Отказ ответчика в постановке на учет является нарушением жилищных прав данной гражданки. Определением районного суда производство по делу по предъявленному иску было прекращено. Апелляционным определением данное определение суда первой инстанции оставлено без изменения. Истица обратилась с кассационной жалобой в Верховный Суд РФ. Судебная коллегия по гражданским делам жалобу удовлетворила, а судебные постановления отменила, указав, в частности, что, прекращая производство по делу на основании абз. 2 ст. 220 ГПК РФ, суд первой инстанции исходил из того, что на стадии постановки граждан на учет в качестве нуждающихся в жилом помещении отсутствует спор о праве на жилое помещение, поскольку жилищные правоотношения еще не возникли, данные отношения носят публичный характер, и такие требования подлежат рассмотрению в порядке, установленном КАС РФ. Между тем, по мнению Коллегии, как видно из содержания искового заявления, обращение в суд с иском в порядке, установленном ГПК РФ, обусловлено необходимостью защиты гражданкой своих жилищных прав относительно постановки на учет нуждающихся в предоставлении жилого помещения по договору социального найма. Поскольку в исковом заявлении действия администрации района не оспариваются, спор связан с реализацией истцом прав, установленных жилищным законодательством, исковое заявление подлежит рассмотрению в порядке, установленном ГПК РФ $\Phi^{5}$.

Однако практика, вырабатываемая Коллегией по административным делам Верховного Суда РФ, носит явно противоположный характер.

Так, постановлением администрации сельского поселения гражданину был предоставлен в собственность за плату земельный участок из земель населенных пунктов, с разрешенным использованием - приусадебный участок личного подсобного хозяйства. Между администрацией и гражданином заключен договор купли-продажи названного земельного участка. Решением Управления Росреестра административному истцу отказано в государственной регистрации права собственности на указанный земельный участок. Гражданин обратился в суд с административным исковым заявлением о признании данного решения незаконным, просил возложить на административного ответчика обязанность осуществить государственную регистрацию права собственности на указанный земельный участок, а также заявил дополнительные требования о признании незаконным протеста и. о. межрайонного прокурора в адрес главы администрации сельского поселения и постановления главы администрации сельского поселения. В обоснование заявления было указано, что отказ регистрирующего органа, протест прокурора и постановление противоречат положениям действующего законодательства и нарушают право данного гражданина на приобретение зе-

${ }^{5}$ Определение Судебной коллегии по гражданским делам Верховного Суда РФ от 24 июля 2018 г. № 78-КГ18-31. Доступ из справ.-правовой системы «КонсультантПлюс». По данному вопросу см. также: Михайлов С. M. К вопросу о правовой природе публичных правоотношений как предмета судебного рассмотрения в административном судопроизводстве // Административное судопроизводство : проблемы и перспективы развития : сб. науч. трудов. М., 2019. С. 104-106. 


\section{Вестник ВГУ. Серия: Право}

мельного участка в собственность за плату. Районный суд прекратил производство по делу на основании п. 1 ч. 1 ст. 194 КАС РФ с разъяснением заявителю его права на обращение в суд в порядке гражданского судопроизводства. Прекращая производство по делу, суд первой инстанции исходил из того, что между заявителем и другим гражданином имеется спор о праве на указанный земельный участок, не подлежащий рассмотрению и разрешению в порядке административного судопроизводства. Апелляционная инстанция оставила это определение без изменения. Попытка первого кассационного обжалования обернулась неудачей, поскольку в передаче кассационной жалобы для рассмотрения в судебном заседании суда кассационной инстанции было отказано. В кассационной жалобе, поданной гражданином в Верховный Суд РФ, ставится вопрос об отмене состоявшихся по делу судебных актов. Судебная коллегия по административным делам пришла к выводу о незаконности обжалуемых судебных постановлений ввиду неправильного применения норм процессуального права, в частности, указав, что поскольку требования административного истца, производство по которым прекращено судом, обусловлены исключительно действиями органов государственной власти (Управления Росреестра), органа государственного надзора (и. о. межрайонного прокурора) и органа местного самоуправления (главы администрации сельского поселения), которые по отношению к гражданину обладают властными полномочиями, они возникли из публичных правоотношений и не носят гражданско-правового характера, защищаемого в исковом производстве ${ }^{6}$.

Вообще, Коллегия по административным делам ВС РФ отстаивает расширительное (или, если угодно, более «административное») понимание подобных дел. Например, принята целая серия решений по схожим требованиям об оспаривании отказов публичной администрации в предоставлении гражданам в собственность земельных участков. Коллегия неизменно приходила к выводу о том, что подобные иски направлены не на установление гражданско-правовых последствий, но именно на оспаривание незаконных решений муниципальных органов ${ }^{7}$.

Следующим дискуссионным моментом является перспектива внедрения в российское административное судопроизводство административной преюдиции. Российской юридической науке и практике хорошо известны все существующие аргументы «за» и «против» указанного фре-

168 номена. Безусловно, идея разгрузки судов за счет возложения обязанности по предварительному обжалованию незаконных административных актов в органах публичной администрации обладает известной притягательностью. Однако опасения по поводу возможного сокращения конституционного права на судебную защиту в российской правовой системе все

${ }^{6}$ Определение Судебной коллегии по административным делам Верховного Суда РФ от 27 июня 2018 г. № 49-КГ18-17. Доступ из справ.-правовой системы «КонсультантПлюс». См. также: Михайлов С. М. Указ. соч.

${ }^{7}$ Определения Судебной коллегии по административным делам Верховного Суда РФ от 27 декабря 2017 г. № 20-КГ17-16 ; от 27 декабря 2017 г. № 20-КГ17-17 ; от 26 апреля 2018 г. № 20-КГ18-4 ; от 26 апреля 2018 г. № 20-КГ18-5. Доступ из справ.-правовой системы «КонсультантПлюс». 
же в настоящее время преобладают (видимо, здесь сказывается «родовая травма» всех постсоветских правопорядков, фрактически с нуля создававших правовую основу административного судопроизводства).

Вместе с тем налоговое законодательство (являющееся в известной мере «полигоном» для различного рода правовых экспериментов, часто небесспорных) предусмотрело исключение из описанного правила. Так, согласно ч. 2 ст. 138 НК РФ, акты налоговых органов ненормативного характера, действия или бездействие их должностных лиц (за исключением актов ненормативного характера, принятых по итогам рассмотрения жалоб, апелляционных жалоб, актов ненормативного характера фредерального органа исполнительной власти, уполномоченного по контролю и надзору в области налогов и сборов, действий или бездействия его должностных лиц) могут быть обжалованы в судебном порядке только после их обжалования в вышестоящий налоговый орган в порядке, предусмотренном настоящим кодексом. Полагаем, что в целом осторожность российской правовой системы в вопросе внедрения административной преюдиции заслуживает одобрения.

Еще одним потенциально проблемным моментом является установление публичной правовой природы субъектов принятия обжалуемых решений (правовых актов). Согласно п. 2 ч. 2 ст. 1 КАС РФ в порядке, предусмотренном кодексом, суды рассматривают и разрешают подведомственные им административные дела об оспаривании решений, действий (бездействия) органов государственной власти, иных государственных органов. Как пояснил Верховный Суд РФ в упомянутом постановлении Пленума 2016 г., под иными государственными органами понимаются, в частности, Центральная избирательная комиссия Российской Федерации, другие избирательные комиссии, Счетная палата Российской Федерации (п. 2).

Однако оспаривание административных актов органов власти неизбежно актуализирует более общую проблему понимания данного субъекта права и отграничения его от иных коллективных субъектов. Дело в том, что система государственного управления в Российской Федерации носит объективно сложный характер. Это проявляется в том числе в довольно специфическом правовом регулировании статуса различного рода вспомогательных, создаваемых при официальных органах исполнительной власти координационных структур.

Приведем в качестве иллюстративного примера рассмотренное Конституционным Судом РФ дело по комиссии по радиочастотам. Российским законодательством предусматривалось создание при уполномоченном фредеральном органе исполнительной власти некой координационной комиссии по радиочастотам. Более того, ст. 22, 23, 24 и 30 Федерального закона от 7 июля 2003 г. № 126-ФЗ «О связи» были установлены конкретные полномочия государственной комиссии по радиочастотам в сфрере регулирования использования радиочастотного спектра (в том числе разработка таблицы распределения полос частот между радиослужбами Российской Федерации и плана перспективного использования радиоча- 


\section{Вестник ВГУ. Серия: Право}

стотного спектра, подлежащих утверждению Правительством РФ, рассмотрение предложений саморегулируемых организаций и отдельных операторов связи о пересмотре названных таблицы и плана, принятие решения о выделении полос радиочастот в полосах категорий совместного пользования радиоэлектронными средствами любого назначения и преимущественного пользования радиоэлектронными средствами гражданского назначения, в частности для получения лицензии на использование радиочастотного спектра, выдаваемой федеральным органом исполнительной власти в области связи, определение порядка проведения экспертизы о возможности использования заявленных радиоэлектронных средств). Некоторые из этих полномочий производили впечатление классически властных, исполнительно-распорядительных. Заявитель (парламент одного из субъектов РФ - Дума Корякского автономного округа) настаивал на том, что оспариваемые положения возлагали осуществление властно-распорядительных и контрольных полномочий исполнительной власти в области связи на орган, не входящий в структуру федеральных органов исполнительной власти и не являющийся юридическим лицом, что, по мнению заявителя, противоречило ст. 10, 11 (ч. 1), 15 (ч. 1), 55 (ч. 3) и 110 Конституции РФ, Уставу Международного союза электросвязи, Конвенции Международного союза электросвязи и Регламенту радиосвязи.

Признание названной комиссии федеральным органом исполнительной власти действительно породило бы неконтролируемые последствия для системы государственного управления в Российской Федерации. В этом случае легализация ее фрункционирования стала бы невозможной по причине создания последней в порядке, не предусмотренном для «классических» государственных органов, а установление такого грубого нарушения привело бы к необходимости упразднения всех подобных

일 структур. Конечно, одним из сравнительно приемлемых вариантов решения могла стать квалификация комиссии некоммерческой организацией, наделенной отдельными государственными или иными публичными полномочиями.

Однако Конституционный Суд РФ сформулировал иную, не лишен-

170 ную определенного изящества правовую позицию: государственная комиссия по радиочастотам не является федеральным органом исполнительной власти, ее права не тождественны правам таких органов, и в силу своей природы она не может осуществлять нормативно-правовое регулирование. Федеральный закон «О связи» наделяет ее статусом органа при федеральном органе исполнительной власти в области связи и соответствующими координационными функциями. Ее решения служат выполнению технических задач регулирования использования радиочастотного спектра и, как следует из данного Федерального закона и Положения о Государственной комиссии по радиочастотам, оформляются протоколами заседаний и приобретают обязательный для всех органов исполнительной власти, юридических и фризических лиц характер по- 
стольку, поскольку утверждаются Министерством информационных технологий и связи Российской Федерации как полномочным федеральным органом исполнительной власти в области связи либо согласованным решением данного органа и других заинтересованных фредеральных органов исполнительной власти ${ }^{8}$.

Таким образом, практика Конституционного Суда РФ позволяет сделать вывод о том, что подобные организации не вправе принимать административные акты; таковыми будут только решения государственных органов.

В завершение данной статьи предлагаем рассмотреть проблему подсудности административных дел, связанных с оспариванием решений организаций, не являющихся органами публичной власти.

Полагаем, что в данном случае мы имеем дело с частным проявлением вышеописанных тенденций столкновения, с одной стороны, безусловного признания за гражданами и организациями права на судебное обжалование любых нарушающих их права, свободы и законные интересы актов, а с другой - неоднозначными интерпретациями предмета КАС РФ в судебной практике. Другими словами, право граждан на обжалование любых решений, действий и бездействия не ставится (и не может ставиться) под сомнение; однако определение подведомственности и подсудности нередко носит дискуссионный характер.

Итак, согласно п. 3 ч. 2 ст. 1 КАС РФ в порядке, предусмотренном названным кодексом, суды рассматривают и разрешают административные дела об оспаривании решений, действий (бездействия) некоммерческих организаций, наделенных отдельными государственными или иными публичными полномочиями, в том числе саморегулируемых организаций субъектов профессиональной деятельности, если оспариваемые решения, действия (бездействие) являются результатом осуществления (неосуществления) указанных полномочий.

Верховный Суд РФ в п. 2 постановления Пленума 2016 г. пояснил: «В то же время не подлежат рассмотрению по правилам КАС РФ не связанные с реализацией публичных полномочий дела по внутрикорпоративным спорам, возникающим между адвокатами и адвокатскими палатами, нотариусами и нотариальными палатами, медиаторами и постоянно действующим коллегиальным органом управления саморегулируемой организации медиаторов, а также между членами и органами управления иных саморегулируемых организаций, которые подлежат разрешению в исковом порядке. Дела об оспаривании решений, действий (бездействия) саморегулируемых организаций субъектов предпринимательской деятельности рассматриваются в порядке, предусмотренном АПК РФ».

${ }^{8}$ По делу о проверке конституционности отдельных положений Федерального закона «О связи» в связи с запросом Думы Корякского автономного округа : постановление Конституционного Суда РФ от 28 февраля 2006 г. № 2-П. Доступ из справ.-правовой системы «КонсультантПлюс». 
Нетрудно догадаться, что Судебная коллегия по гражданским делам Верховного Суда РФ с нескрываемым удовлетворением воспроизводит указанную правовую позицию Пленума в своих решениях. Например, именно в качестве гражданско-правового был квалифицирован спор об оспаривании нотариусом Ш. решения президента Нотариальной палаты Самарской области о проведении в отношении ее повторной проверки исполнения профессиональных обязанностей нотариуса и о признании незаконным и недействительным решения коллегиального исполнительного органа Нотариальной палаты об объявлении ей строгого выговора ${ }^{9}$.

С другой стороны, Судебная коллегия по административным делам Верховного Суда РФ весьма последовательно (и довольно отважно) находит публично-правовой элемент практически во всех делах, попадающих на рассмотрение в указанную коллегию. Так, иск об оспаривании решения совета адвокатской палаты о порядке участия адвокатов в качестве защитников в уголовном судопроизводстве и в качестве представителя в гражданском и административном судопроизводстве (квалифицированный судами низшего и среднего звеньев как гражданско-правовой) был признан Коллегией административным ввиду того, что оспариваемое решение принято в рамках реализации возложенных законом на адвокатскую палату публичных полномочий (при том, что заявленные требования, по мнению Коллегии, не являются внутрикорпоративным спором между адвокатом и адвокатской палатой) ${ }^{10}$.

Можно привести следующие более очевидные примеры рассмотренных Судебной коллегией по административным делам Верховного Суда РФ дел об оспаривании решений организаций, реализующих публичные фуннцци:

m 1) об оспаривании актов (также бездействия) Бюро технической ин이 вентаризации ${ }^{11}$;

2) об оспаривании отказа Федерального государственного казенного учреждения «Восточное региональное управление жилищного обеспечения» Министерства обороны РФ в выдаче справки о сдаче служебного жилого помещения ${ }^{12}$;

${ }_{9}^{9}$ Определение коллегии по гражданским делам Верховного Суда РФ от 15 мая 2017 г. № 46-КГ17-2. Доступ из справ.-правовой системы «КонсультантПлюс».

${ }^{10}$ Кассационное определение коллегии по административным делам Верховного Суда РФ от 15 марта 2019 г. № 11-КГ18-41. Доступ из справ.-правовой системы «КонсультантПлюс».

${ }^{11}$ Определение коллегии по административным делам Верховного Суда РФ от 1 июня 2017 г. № 14-КГ17-9. Доступ из справ.-правовой системы «КонсультантПлюс».

12 Определение коллегии по административным делам Верховного Суда РФ от 28 февраля 2018 г. № 56-КГ17-38. Доступ из справ.-правовой системы «КонсультантПлюс». 
3) об оспаривании действий филиала федерального государственного бюджетного учреждения «Федеральная кадастровая палата Федеральной службы государственной регистрации, кадастра и картографии» ${ }^{13}$.

Однако настоящим «крестовым походом» на ограничительное понимание административных дел (и следовательно, предмета КАС РФ) стало дело об оспаривании гражданином П. отказа государственного казенного учреждения Удмуртской Республики «Центр занятости населения Игринского района» о признании его безработным.

Обстоятельства дела таковы. Гражданин П., зарегистрированный в качестве безработного, не явился на повторный прием в соответствующий центр занятости населения, в связи с чем ему было отказано в признании его безработным. Районный суд рассмотрел административный иск по КАС РФ (и удовлетворил его частично). Суд апелляционной инстанции (апелляционная коллегия суда субъекта) производство по КАС РФ прекратил, определением судьи суда субъекта лицу было отказано в передаче кассационной жалобы для рассмотрения в судебном заседании президиума данного суда (Верховного Суда Удмуртской Республики).

Примечательно, что гражданин П. (очевидно, смирившийся с невозможностью рассмотрения дела в порядке административного судопроизводства) в своей кассационной жалобе, направленной в Верховный Суд РФ, просил отменить указанные судебные акты и направить дело в суд первой инстанции для рассмотрения в порядке именно гражданского судопроизводства.

Однако кассационная жалоба попала в Судебную коллегию по административным делам Верховного Суда РФ, которая воспользовалась случаем сделать, как представляется, решительную попытку расширения горизонтов применения КАС РФ. Во-первых, Коллегия отвергла предположение о том, что данный спор сопряжен с рассмотрением также вопросов гражданско-правового характера. Во-вторых, в данном случае публичный характер реализуемых центром занятости населения функций автоматически презюмировался (во всяком случае в кассационном определении нет даже краткой аргументации данного тезиса). Наконец, в-третьих, Коллегия подчеркнула, что автоматический отказ судов в рассмотрении дела по КАС РФ носил формальный характер; даже если имело бы место нарушение правил подведомственности, необходимо было бы обосновать, каким образом рассмотрение дела по КАС РФ само по себе могло бы привести к принятию (судом первой инстанции) неправильного по существу решения.

По сути, Коллегия в ситуации малопонятного ограничения предмета КАС РФ вынужденно провозгласила приоритет существа решения над процессуальной формой, поощряя суды нижестоящих инстанций к рассмотрению именно административных исков: «Правильное определе-

${ }^{13}$ Определение коллегии по административным делам Верховного Суда РФ от 3 августа 2017 г. № 18-КГ17-91. Доступ из справ.-правовой системы «КонсультантПлюс». 


\section{Вестник ВГУ. Серия: Право}

ние вида судопроизводства, в котором подлежат защите права и свободы гражданина или организации, зависит от характера правоотношений, из которых вытекает требование лица, обратившегося за судебной защитой, а не от избранной им формы обращения в суд (подача заявления в порядке административного судопроизводства или искового заявления)». Руководствуясь вышеописанными мотивами, Коллегия отменила апелляционное определение и вернула дело на новое рассмотрение (в коллегию по административным делам суда субъекта) ${ }^{14}$.

Таким образом, развитие норм о подведомственности и подсудности административных дел в КАС РФ и судебной практике носит спорный характер. С одной стороны, нельзя не приветствовать осторожность в плане внедрения административной преюдиции, что напрямую обусловлено признанием безусловного, абсолютного характера права невластных лиц на судебную защиту от незаконных действий публичной администрации. С другой стороны, явный «цивилистический» крен сужает сфреру применения весьма лояльных для граждан и организаций норм КАС РФ. Полагаем, наличие гражданско-правовых требований, а также отсутствие у субъекта, принявшего публично-правовое по сути решение, статуса органа публичной власти не должно автоматически приводить к рассмотрению соответствующего дела по правилам ГПК РФ. Наиболее корректным представляется противоположный подход о необходимости рассмотрения таких исков по правилам административного судопроизводства (что, собственно, и нашло в настоящее время свое отражение в практике Судебной коллегии по административным делам Верховного Суда РФ).

\section{Библиографический список}

Михайлов C. M. К вопросу о правовой природе публичных правоотношений как предмета судебного рассмотрения в административном судопроизводстве // Административное судопроизводство : проблемы и перспективы развития : сб. науч. трудов. М. : РГУП, 2019. С. 101-110.

Опалев P. О. Предмет судебной защиты в административном судопроизводстве // Арбитражный и гражданский процесс. 2021. № 4. С. 18-22.

\section{References}

Mikhailov S. M. To the question of the legal nature of public legal relations as a subject of judicial review in administrative court proceedings // Administrative proceedings: problems and development prospects: collection of scientific works. M. : RGUP, 2019. P. 101-110.

Opalev $R$. O. The subject of judicial protection in administrative proceedings // Arbitration and Civil Process. 2021. № 4. P. 18-22.

${ }^{14}$ Кассационное определение коллегии по административным делам Верховного Суда РФ от 27 мая 2020 г. № 43-КА20-2. Доступ из справ.-правовой системы «КонсультантПлюс». 


\section{Для иитирования:}

Давыдов К. В. Подведомственность и подсудность административных дел в Российской Федерации // Вестник Воронежского государственного университета. Серия: Право. 2021. № 3 (46). C. 164-175. DOI: https://doi.org/10.17308/vsu.proc.law.2021.3/3548

\section{Recommended citation:}

Davydov K. V. Jurisdiction and jurisdiction of administrative cases in the Russian Federation // Proceedings of Voronezh State University. Series: Law. 2021. № 3 (46). P. 164-175. DOI: https://doi.org/10.17308/vsu.proc.law.2021.3/3548

Новосибирский государственный университет эконолики и управления "НИНХ"

Сибирский университет потребительской кооперации

Давыдов К. В., кандидат юридических наук, доцент

E-mail:davkon@yandex.ru
Novosibirsk State University of Economics and Management

Siberian University of Consumer Cooperation

Davydov K. V., Candidate of Legal Sciences, Associate Professor

E-mail:davkon@yandex.ru 